\title{
Status of Job Opportunities and Employment of Library and Information Science Professionals in India An Analysis of Job Advertisements
}

\author{
${ }^{1}$ Dr. Manoj Kumar Sinha, ${ }^{2}$ Brojesh Kumar Pandey \\ ${ }^{1}$ Associate Professor and Head of the Department, \\ Department of Library and Information Science, \\ Assam University, Silchar-788 011 \\ ${ }^{2}$ Department of Library and Information Science, Assam University, Silchar-788 011
}

\begin{abstract}
The career in library includes areas like library and information systems management, classification/cataloguing systems, bibliography, documentation, preservation and conservation of manuscript, collection management, information systems and technology, research methodology, computer applications, reference, statistics and management, information processing, archives management, indexing, library planning, etc. Now-a-days, a number of career prospects are available in Library and Information Science. The qualified and trained professionals are employed in various libraries and information centres. The present study aims to identify and assess the job opportunities for the professionally qualified LIS professionals in the area of Library and Information Science.
\end{abstract}

The data required to carry out the study have been collected from the printed weekly issues of 'Employment News' and the 'LIS Link: a 'LIS Job Portal'. The data collected have been represented through tables and figures. The data collected have been analysed to reflect the different aspects of LIS Profession, such as month wise, state wise, category wise (whether reserved or unreserved; teaching or non-teaching position), nature wise (whether permanent or temporary), source wise, level wise distribution of advertisements. Moreover, a preliminary data was collected after scanning the available literature and data pertaining to the number of library science graduates produced every year and their employability.

The study puts forwarded some suggestions to ensure employability of LIS Professionals in India showing state wise job opportunities and employment. The study was delimited the job advertisements published during January 2011 to December 2011 only. However, the same research work can be carried out on a large scale to have a generalised conclusion highlighting the scenario of job opportunity and output of LIS professionals in the Indian context.

From the data available for intake capacity for BLIS, MLIS, and Research Programme, the number of advertised posts are very less in number in comparison to production of fresh graduates which creates problems in searching jobs for the LIS Professionals. Therefore the Govt. of India / State Govt. should come forward to create requisite number of posts in different Schools, Colleges, Universities, Institutions and Public Libraries so that those maximums qualified passed out Graduates, Post Graduates and research degree holders may be appointed to the respective positions as per their eligibility.

Key Words: Job Advertisements, Job Opportunities-India, Librarianship, Print and Electronic Media, Library and Information Science Professionals-India

\section{Introduction}

Due to the rapid growth in the number of learning institutions all over the country, the necessity and the importance of libraries is also growing. Moreover, with the industrialisation, economic and social growth, many new professions have emerged in the last two hundred years. More particularly the $20^{\text {th }}$ century has witnessed the growth of hundreds of new professions. Librarianship is one such profession that emerged in the $19^{\text {th }} / 20^{\text {th }}$ century when corpus of knowledge multiplied geometrically requiring rapid expansion in its nature of work and services of knowledge organisation, retrieval and dissemination. Thus, librarianship is a growing field, which has by now attained the status of a separate discipline in the universe of knowledge. With the introduction of information and communication technology, the definition of the Library as well as the Librarianship has changed. Earlier, the Library was considered as the store house of books and the Librarian, as the custodian of books. But now, the role of traditional librarian is fast evolving from the custodian of books to a facilitator who 
locates the right information. It is one of the duties of the Librarian to help users to find the right information at the right time as per their requirement and use it effectively and efficiently.

From the beginning of the $21^{\text {st }}$ century, Library and Information Science Professionals working in India continuously witnessed different paradigm shifts till date, like shift from paper to electronic media which in modern times the dominant form of information retrieval, storage and dissemination. Now there is an increasing demand for accountability along with focus on customer services, performance evaluation, bench marking and continuous improvement. Moreover, various new tasks and terms have evolved like Quality Management, Total Quality Management; new forms of work organizations such as work teams, job sharing, outsourcing, telly work, re-engineering etc. But among all the factors, the largest factor that has forced this paradigm shift and caused significant change in the area of Library Science by introducing new concepts and services is nothing but the Information and Communication Technology (ICT). The introduction of Internet and WWW has changed the ways of accessing and locating information and thus changed the functions of academic libraries and academic library professionals in the modern information society.ICT have introduced a new service environment in libraries that has crossed formal boundaries much faster, where there is calculated risk as well as opportunities also. Thus Singh and Pinki realized that today's environmental pressures are forcing libraries to focus on accelerating technology, innovation, technical complexities, social and legal issues, cost, risk, competence, skills of staff and technology itself. Therefore, the library professionals have to act in a proactive manner to support the twenty-first century educational change.

Library \& Information Science (LIS) courses have lot of potential to develop the knowledge and skills required to sustain and survive in the present day knowledge society. Globalization and liberalization has opened up multiple career options to the LIS professionals. The traditional roles of LIS have changed with the advances in Information and Communication Technologies. LIS professionals are expected to be academics of higher order with competence to work in a hypertext, networked, digital environment. Hence, the LIS education should impart the learners, the necessary skills to gain employment upon graduation and to develop the vision and understanding to help them cope better with the rapidly changing world.

Now days, a number of career prospects are available in Library and Information Science. The qualified and trained professionals are employed in various libraries and information Centres. LIS professionals can select the type of library as per their own interest. Thus there is a very bright future prospect for LIS professional. And only the trained personnel in LIS can have employment opportunities in the various sectors.

\subsection{Statement of the Problem}

The statement of the problem of the study is entitled as "Status of Job Opportunities and Employment of Library and Information Science Professionals in India: An Analysis of Job Advertisements." A comprehensive study on the job advertisements published in different media for the LIS professionals during the year 2011 is made. The introduction of ICT widens the areas in Library and Information Science. The Job Prospects thus, for Library and Information Science Professionals covers a huge area. Career in LIS is multidimensional, ever growing and bright. Besides, the last two decades have definitely witnessed the tremendous change in the library science profession and education system in India. With the advancement of IT, different new designations have evolved for LIS professionals. Thus it is very important to study the job opportunities for LIS professionals for fast dissemination of advertisement. The study aims to create the statistics of the job on various aspects and asses the demand for the Library Professionals in recent times. It is hoped that the study will be benefitted for both the LIS students and LIS professionals and let them know the market demand for the LIS professionals under various designations and the required qualifications and skills and also the need for further education and training.

\subsection{Objectives of the Study}

Every study aims to reveal something new. Thus each and every study must or should have its important objectives to be fulfilled. The objective of the study is required both for the researcher and for the reader which let them know at a glance the main requirements and the need for which the research is being conducted.

The main objectives of this study are to present the statistics of the job on various aspects and to asses the demand for the Library Professionals in recent times. With this main objective following are some allied objectives of the study: 
$>$ To analyse the changing trends of job opportunities for Library and Information Science Professionals on most diversified technological environment;

> To study the LIS job advertisements applying various study criteria like Month wise, State wise, Source wise, Category (Reserved/Unreserved; Teaching/Non-Teaching) wise, Nature (Permanent/Temporary) wise, Level wise etc;

$>$ To present the current status of job opportunities for library and information science professionals at the national level in general;

$>$ To assess and examine the demand for the LIS professionals in the job market; and

$>$ To understand essential and desirable competencies, and other skills that employers advertise for the various positions of jobs for fresh LIS Graduates and Post-Graduates and working LIS Professionals.

\subsection{Scope of the Study}

The study is conducted on "Status of Job Opportunities and Employment for Library and Information Science Professionals in India: An Analysis of Job Advertisements."The study is confined to study of fresh graduates, post-graduates and working LIS Professionals in India who are looking for better jobs and opportunity. The media scanned or covered for this study is confined to print version of the Employment News, and the LIS Job Portals mainly the LIS Link (http://www.lislinks.com). The study is also restricted for the year 2011. Some other media like some regional and national newspapers are also consulted. Care has been taken to cover and include all the advertisements published for LIS Professionals from the above mentioned sources.

\subsection{Delimitation of the Study}

The present study was delimited to the two sources of information from where data pertaining to job opportunity and employment has been collected. These two sources are 'Employment News' and the 'LIS Link'. But there are many other national and regional print as well as electronic media which have not been consulted. There are many leading private and other institutions which sometimes may publish their advertisement in regional and other national newspapers. So, these types of advertisements have not been included in the present study due to paucity of time for completing this survey and analysis work within few months.

Thus the present study has been delimited to the job advertisements published in Employment News and LIS Link, and LIS Job Portal during the period January 2011 to December 2011. Due to the paucity of time, advertisements published in other media have not been taken into account. This may be taken as a pilot study to carry out the same study at large scale to draw some important findings pertaining to generation of fresh LIS graduates and giving job opportunity to them to earn their livelihood from the novel profession of supporting teaching -learning activities of the academic communities.

\section{Review Of Literature}

Review of related literature is conducted to enable the researcher to get a clear understanding about the specific field of study. It also helps the researcher to have an insight into the tested methods, procedures and interpretations of similar studies conducted elsewhere.

Dasgupta (2009) discussed about developing the employability of Library Professionals in this new era of Information and Communication Technology and also in this globalised educational environment. He pointed out that the libraries all over the world are now responding with adaptability, creativity and flexibility. In India also the present librarians are in a society which is exercising the influence of technological revolution and rapid societal changes. All the information professionals in India are now in a state of both exhilaration and anxiety as a result of these societal changes. According to him, library and information professionals in India are confronting various dislodge in their field from the beginning of the $21^{\text {st }}$ century. This dislodge includeshifting from paper to electronic media, demand for more focus on customer services, performance measurement, introduction of new form of work organization, etc. .In this paper, he discussed different aspects of Library Profession, role of universities in the development of LIS professionals, Library schools of Indian Universities during pre and post-independence era, current trends and problems of LIS education in India and further made suggestions/recommendations to build and develop better professionals in the field of Library and Information Science. 
Few of his recommendations are stated here briefly which are : To establish a National Council for Accreditation of Library Schools (NACALIS) under the provisions of LIS Education Act; Setting up a National Institute for LIS by Govt. of India; A National Policy for LIS Education; and Adequate infrastructural facilities for LIS schools etc. Finally, according to him, LIS professionals have to acquire, evolve and bring up various types of competencies that are the need of this modern information age. They have to be 'Proactive' rather than 'Passive'.

Susan (2011), a Ph.D. scholar, in his work "Impact of Information Communication Technology (ICT) on Professional Development and Educational Needs of Library Professionals in the Universities of Kerala" highlighted the required skills for LIS professionals and impact of ICT on all components of the academic library system in India.The aim of his study was to assess whether the developments in information communication technologies have any influence on the library professionals' professional development, and also the need for further education and training in the profession and evaluate their skills in handling developments in ICT. He pointed out that the use of ICT tools in majority of the Indian Universities to collect and disseminate information is evolving slowly. Since technology has dominated every operations and services in library, so according to him,information professionals in the academic institutions have to counter the changes and expectations of users, and be conciliatory in developing new skills and levels of awareness.In addition to this, they should posses other skills, like business and management skills, teaching, leadership, etc.

Mahapatra (2006) in his paper "LIS Education in India: Emerging Paradigms, Challenges and Propositions in the Digital Era" found that libraries all over the world are moving beyond the conventional framework and giving the footprints of radical changes in the skeletal concept of LIS profession. Thus he concluded that the librarians of 21 st century have to prepare themselves suitable for working in network environment and should also acquire necessary skills such as leadership; exploiting information handling; communication, crisismanagement, team building and decision making, etc. So, the library professionals are in dire need toacquire the relevant skills and expertise to track the world of information and become competent enough to serve in a digital culture. An attempt is made here to project issues related to the LIS education in India and suggests some proposals in this respect based on routine features and experiences. The study also proposes the core elements of the LIS curriculum and the vision of LIS education in India for coming decade. The paper also stresses the needs of revised course contents and allied challenges for readiness of Indian LIS education in digital era.

Singh (2003) conducted a study on "Library and Information Science Education in India: Issues and Trends" and traces the emergence of library and information science (LIS) education in India before and after independence. Describes the current status, the different patterns and levels of LIS education, as well as the research programmes being offered by various universities, provides an overview of the institutions providing LIS courses at various levels through regular courses and open schools, emphasizes the need for having a national level accreditation body to maintain uniformity and standards in LIS education. Discusses the problems affecting the status of LIS education and suggests ways to solve these problems and the approaches to prepare the LIS professionals to face the growing challenges of the job market.

Babu (2007) in his study on "Trends, Challenges and Future of Library and Information Science Education in India" found that the technological revolution paved the challenges for the library and information science (LIS) schools not only in India but also in the west. Responsibilities of LIS departments and teachers are increasing to produce best LIS professionals to lead the 21 st century librarianship. The major responsibility of the LIS departments in India is to groom LIS students in the philosophy, knowledge, and professional values of librarianship, as practiced in libraries and in other contexts, and as guided by the vision of the $21^{\text {st }}$ century librarianship. LIS education and training facilities in India are undergoing rapid changes. During the past 10 years, the number of library schools/departments has grown substantially, both for regular and distance education programmes. Reorientationhas been common in most LIS departments and review and revision in curriculum has also been noticed. The quality of LIS educators has also improved and research output is experiencing new dimensions. Increase in the use and access to information and communication technologies (ICT) for LIS education is now more evident. This paper discusses the challenges LIS education faces in the 21 st century and how to make LIS education more relevant and effective.

Kumar and Sharma (2010) present a historical perspective of Library and Information Science (LIS) education in India, and trace the growth and development of the subject. LIS education began under the patronage of the erstwhile Maharaja of Baroda when he invited an American librarian to set up public libraries 
in the state. After independence, Library Associations in the country continued with the efforts of developing LIS education in India. The discipline got recognition with the introduction of various courses at the university level. It has seen periods of growth and maturation. The recommendations of National Knowledge Commission provide an opportunity for reforms and changes in the educational system that needs to be grabbed.

Joshi (2010) carried out a study on "Library and Information Science Education in India: Some Government Initiatives"and discussed the various initiatives taken by different Government Agencies like Radhakrishnan Commission; Kothari Commission;National Policy on Education-1968, 1986, 1992; National Knowledge Commission and functioning of institutions such as UGC, NAAC, DEC have influenced the entire higher education sector. Moreover, The Government of India has also taken keen interest in library matters through Advisory Committee for Libraries; Working Group of Planning Commission; National Policy on Library and Information System, etc. UGC has shown keen interest in LIS education through its various committees and subject panels. The Library Committee; Review Committee and the two CDCs constituted in 1990 and 2000 have been largely responsible for the present state of LIS education in India.

Sarkhel (2006), carried out a study on "Quality Assurance and Accreditation of LIS Education in Indian Universities" Issues and Perspectives" which provides a brief overview of the present status and problems of Library and Information Science (LIS) education in Indian universities with an emphasis on the need for its internal quality assurance and accreditation by an external agency. The University Grants Commission's (UGC) efforts for the improvement of quality of LIS education have also been highlighted. A set of objective indicators has been developed on the basis of an understanding of the global developments in the activities and services of libraries and information centres, the national environment, the outcome of National Assessment and Accreditation Council (NAAC) and the observations and recommendations arising fromdifferent national level seminars and workshops to facilitate the assessment and accreditation of LIS education.

Singh and Malhan, conducted a study on"Trends and Issues in LIS Education in India". Their study is based on review of literature, interviews with students, employers and experts, and personal experience of the authors. The purpose of this study was to identify the emerging trends and lingering issues in Library and Information Science (LIS) education in India, and give suggestions to align LIS education programs with jobmarket and end-user expectations.

Gowda (2009) conducted a survey on "Satisfaction Levels Related to Management Issues among LIS Professionals" which explored the fact that the LIS professionals should be encouraged to participate actively in library and other related activities of the campusto increase their perception. Their opinions are to be taken seriously and implement their valid and concrete suggestion should be implemented in practice. This type of positive approach from the authority improves satisfaction level of the professionals.

Jeevan (2003) has undertaken a research on "Job Prospects in Library \& Information Science: A Study of Vacancies Notified in the Employment News from 1998 to 2001". He consulted printed version of employment news to assess the job opportunities in Library and Information science profession. He presented the data gathered in 25 tables and analysed to reflect the major employers- the central/state govt. and/or its allied institutions and private sectors; nature of job whether permanent or temporary; reservation trends; essential and desirable qualifications; prior experience; and the prominent employers and categories of jobs etc. Assumptions are countered in his paper by making few suggestions regarding what is to be done by all concerned, be it the student, employer or professional bodies.

Sridhar (1999) also conducted a research on "Skill Requirements of LIS Professionals in the E-world" and found that all pervasive information technology (e-world) has affected significantly the rendering of library and information services, but adoption of IT to library services has not been smooth. In addition to professional knowledge, Librarianship is expected to have some knowledge in the areas of management, foreign languages, statistics, computers etc. New professionals of e-world of $21^{\text {st }}$ century need to have not only knowledge and skills in the area of Information Technology but also matching 'will' to carry out the services in the new media and means. Any significant gap between the knowledge and corresponding skills required is dangerous. His paper cites various levels of skills required by LIS professionals and highlight skills starting from computer literacy to electronic publishing and marketing.

\section{Research Methodology}

Qualitative research methods are being used to conduct this study. This study is descriptive in nature with main objective to analyze the library job advertisements in Govt. and Non Govt. sectors of India to 
understand the nature and conditions of the job requirements set by the employers and other hiring agencies and the market trends in the era of technological advancements.

The Job advertisements advertised within the period from January to December 2011 have been selected for this study. The sources of these advertisements are mainly leading National and Local newspapers; especially the Employment News and the LIS Link which is a LIS Job Portal. Most of advertisements are downloaded from these sources or their reference were noted down and later searched from the newspapers. The data entry is done in MS Access and further the data has been tabulated and graphs have been prepared using MS-Excel and these data has been analysed to come upon generalised findings and a meaningful conclusion is drawn.

\section{Data Analysis And Interpretations}

The required data for the present study has been collected, during the period from $1^{\text {st }}$ January 2011 to $31^{\text {st }}$ December 2011 which has been analysed and interpreted using Content Analysis method. Content analysis is a research technique used for making replicable and valid inferences from texts (or other meaningful matter) to the contexts of their use (Krippendorf 2004).

In this study, the required data has been collected mainly from two sources; viz. 'Employment News' and 'LIS Link' which is a LIS Job Portal. During the period of the study, the advertisement published in the weekly newspaper "Employment News " has been scanned and a total of 50 issues of Employment News between the above mentioned periods have been consulted and analysed for the purpose. Moreover the LIS Link, a LIS Job Portal have also been consulted and the required data between the period of study has been collected and analysed for arriving to the important findings as per the requirement of the objectives.

\section{Month Wise Analysis Of Advertisement Published During January To December 2011}

The result as indicated in Table-.1 shows the status of the month wise details of Advertisements published during the January to December 2011. After scanning of all issues published during the period of study, altogether 277 numbers of advertisements related to job opportunity for LIS professionals have been published which varies from junior positions to senior ones. The month-wise details of advertisements published during 2011 have been tabulated in Table-1.

Table -.1: Month Wise Analysis of Advertisements Published During the January to December 2011 $(\mathbf{N}=\mathbf{2 7 7})$

\begin{tabular}{|l|l|l|}
\hline Months & No. of Post Advertised & Percentage (\%) \\
\hline January & 52 & 18.77 \\
\hline February & $\mathbf{5 6}$ & $\mathbf{2 0 . 2 1}$ \\
\hline March & 47 & 16.97 \\
\hline April & 9 & 3.24 \\
\hline May & 19 & 6.86 \\
\hline June & 10 & 3.61 \\
\hline July & 13 & 4.69 \\
\hline August & 9 & 3.24 \\
\hline September & 28 & 10.10 \\
\hline October & 9 & 3.24 \\
\hline November & 15 & 5.41 \\
\hline December & 10 & 3.61 \\
\hline Total & 277 & 100.00 \\
\hline
\end{tabular}

Out of 277 number of advertisements, it was found that maximum number of posts are advertised during the months of February $(56=20.21 \%)$, January $(52=18.77 \%)$ and March $(47=16.97 \%)$ respectively whereas minimum number of advertisements $(9=3.24 \%)$ each $)$ have been published during the months of April, August and October 2011. From the study it is evident that the peak months for advertisements are January, February, March, September, May and October when maximum advertisements are published for employment. While April, June, July, August, October and December months are having less than 10 advertisements.

But it is to be noted that each months one can find advertisements for LIS jobs in the employment News, which is a best medium for advertisements for job opportunities and employment. Therefore, definitely, the Employment News is a popular media for advertisements for LIS professionals. All the LIS professionals must subscribe or refer to the Employment News for the job posts advertisements.

LIS Link a LIS professional Social Networking site developed by the Indian LIS professional for the benefit of the upcoming LIS professionals who are seeking job. It has developed a forum for job advertisements. 
The information pertaining to job has been posted by some of the member LIS professionals for the benefit of the others. As soon as the advertisement information has been posted, instantly, there is provision in the system to send alerts to all the members which enables the LIS professionals to go through the detail advertisements published in either Employment News or organisations web sites or on any printed and electronic media.

\subsection{State -Wise Distribution of the Advertisements Published during Jan to Dec 2011}

Table-2: State Wise Distribution of Advertisements Published During Jan - Dec 2011 (N=277)

\begin{tabular}{|c|c|c|c|}
\hline Name of the States / UT & $\begin{array}{l}\text { No. of Posts } \\
\text { Advertised }\end{array}$ & Percentage (\%) & Rank \\
\hline Andhra Pradesh & 6 & 2.16 & X A \\
\hline Arunachal Pradesh & 2 & 0.72 & XIV A \\
\hline Assam & 2 & 0.72 & XIV B \\
\hline Bihar & 5 & 1.8 & $\mathrm{XIA}$ \\
\hline Chhattisgarh & 4 & 1.44 & XII \\
\hline Delhi & 96 & 34.65 & I \\
\hline Goa & 1 & 0.36 & XV A \\
\hline Gujarat & 3 & 1.08 & XIII A \\
\hline Haryana & 8 & 2.88 & VIII \\
\hline Himachal Pradesh & 9 & 3.24 & VII A \\
\hline Jammu \& Kashmir & 1 & 0.36 & XV B \\
\hline Jharkhand & 2 & 0.72 & XIV C \\
\hline Karnataka & 1 & 0.36 & XV C \\
\hline Kerala & 5 & 1.8 & XI B \\
\hline Madhya Pradesh & 22 & 7.94 & III \\
\hline Maharashtra & 12 & 4.33 & $\mathbf{V}$ \\
\hline Mizoram & 3 & 1.08 & XIII B \\
\hline Orissa & 3 & 1.08 & XIII C \\
\hline Punjab & 11 & 3.97 & VI \\
\hline Rajasthan & 6 & 2.16 & X B \\
\hline Tamil Nadu & 9 & 3.24 & VII B \\
\hline Uttar Pradesh & 38 & 13.71 & II \\
\hline Uttrakhand & 7 & 2.52 & IX \\
\hline West Bengal & 21 & 7.58 & IV \\
\hline Total & 277 & 100.00 & \\
\hline
\end{tabular}

The State- Wise distribution of advertisements published for Library and Information Science (LIS) Professionals during the year 2011. Out of 28 States, the advertisements published for LIS Professionals from 24 states, which have been shown in Table -2 .

From the above Table-2, it has been observed that, the highest no. of post for LIS professionals are advertised for Delhi. Out of a total of 277 no. of posts, 96 no. of posts i.e. $34.65 \%$, are advertised for the libraries and other govt. and non govt. institutions located in Delhi which is followed by Uttar Pradesh $(38=$ $13.71 \%)$, Madhya Pradesh $(22=7.94 \%)$ and West Bengal $(21=7.58 \%)$. Whereas very few posts of LIS Professionals have been published for Arunachal Pradesh, Assam, Chhattisgarh, Goa, Gujarat, Jammu \& Kashmir, Kerala, Jharkhand,, Bihar, , Karnataka and other states.

\subsection{Category Wise Distribution of advertisements ( Reserved / Unreserved of Posts for LIS Jobs}

The Table-3 represents the Category (Reserved/Unreserved) wise distribution of no. of posts advertised during the year 2011 for LIS professionals in India. There are Five Categories, out of which four are under reserved categories such as OBC (i.e. Other Backward Caste), SC (Scheduled Caste), Scheduled Tribe (ST) and Physically Handicapped (PH), and the other is the Unreserved or General category. The no. of posts under unreserved and the different reserved categories are shown in the Table - 3.

Table-5.3: Category Wise (Reserved/Unreserved) Distribution of Posts ( $N=277)$

\begin{tabular}{|l|l|l|l|}
\hline Category & No. of Posts & Percentage & Ranks \\
\hline General/Unreserved (UR) & $\mathbf{2 0 4}$ & $\mathbf{7 3 . 6 4}$ & I \\
\hline
\end{tabular}


Status of Job Opportunities and Employment of Library and Information Science Professionals in

\begin{tabular}{|l|l|l|l|}
\hline Other Backward Caste (OBC) & 33 & 11.91 & II \\
\hline Scheduled Caste (SC) & 21 & 7.58 & III \\
\hline Scheduled Tribe (ST) & 14 & 5.05 & IV \\
\hline Physically Handicapped (PH) & 5 & 1.80 & V \\
\hline TOTAL & 277 & 100.00 & \\
\hline
\end{tabular}

Table- 3 reveals that the highest number of posts advertised is for unreserved category. Out of 277 numbers of posts, $204(73.64 \%)$ posts are available for unreserved category and the remaining posts are reserved for different categories, i.e. OBC, SC, ST, and PH candidates. Out of the total reserved posts, the highest nos. is reserved for $\mathrm{OBC}(33=11.91 \%)$ candidates and the least nos. is reserved for $\mathrm{PH}(5=1.8 \%)$ candidates.

\subsection{Designation Wise Distribution of Number of Posts Advertised}

Table -4: Designation Wise Distribution of Number of Posts Advertised (N=277)

\begin{tabular}{|c|c|c|}
\hline Designations & No. of Posts & Percentage $(\%)$ \\
\hline $\begin{array}{llll}\text { University Librarian } & \text { (Central } & / & \text { Sate } \\
\text { Universities ) } & & & \end{array}$ & 12 & 4.33 \\
\hline $\begin{array}{lll}\text { University } & \text { Librarian } & \text { (Institute/Deemed } \\
\text { Universities ) }\end{array}$ & 18 & 6.50 \\
\hline College Librarian & 7 & 2.53 \\
\hline School Librarian & 2 & 0.722 \\
\hline Librarian in Govt. org./others & 9 & 3.24 \\
\hline Library and Information Officer & 13 & 4.69 \\
\hline Additional Director General & 3 & 1.08 \\
\hline Deputy Librarian & 16 & 5.78 \\
\hline Assistant Librarian & 24 & 8.66 \\
\hline $\begin{array}{lr}\text { Information } & \text { Scientist/Technical } \\
\text { Assistant/Technical } & \text { Officer/Library } \\
\text { Technician } & \\
\end{array}$ & 14 & 5.05 \\
\hline Professional Assistant (PA) & 13 & 4.69 \\
\hline Semi Professional Assistant (SPA) & 10 & 3.61 \\
\hline Library Assistant/Cataloguer & 40 & 14.44 \\
\hline Library and Information Assistant & 39 & 14.07 \\
\hline Library Clerk & 6 & 2.16 \\
\hline Library Attendant & 33 & 11.91 \\
\hline \multicolumn{3}{|l|}{ Teaching Positions } \\
\hline Professor & 5 & 1.8 \\
\hline Associate Professor & 5 & 1.8 \\
\hline Assistant Professor/Reader & 8 & 2.89 \\
\hline Total & 277 & 100.00 \\
\hline
\end{tabular}

The Table-4 represents the designation wise distribution of no. of posts published in different sources for LIS Professionals in the year 2011. Here the various posts published under different designations are included under 19 different designations. From this table, we can see that the highest no. of posts is advertised for 'Library Assistant/Cataloguer'. A total of 40 (14.44\%) no. of posts out of 277, advertised under this designation which is followed by 'Library and Information Assistant' with 39 (14.07\%) and Library Attendant with $33(11.91 \%)$ no. of posts. It can also be seen from the above table that only $2(0.722 \%)$ posts are advertised for 'School Librarian' which is very less as compared to other posts advertised under any designation. It indicates that posts for lower levels are available in more numbers in comparison to top and middle level of posts.

\subsection{Source -Wise Distribution of Advertised Posts for LIS Professionals}

The Source wise distribution of number of posts has been depicted in Table-5 which were published during Jan. - Dec. 2011 for LIS Professionals. These advertisements were collected from two sources viz. the 'Employment News' and the LIS Link: LIS Job Portal. From the results as indicated in Table -5, it was found that that the maximum number of LIS related job requirements / posts have been advertised in Employment News than the LIS Link. Some of the advertisements are found in both the sources. Out of a total of 277 number of posts advertised, Employment News contains $139(50.18 \%)$ whereas $102(36.82 \%)$ number of posts were collected from LIS Link and $36(13 \%)$ number of advertisements were published in both the sources. The 
employment News is authentic source of advertisement information. Some enthusiastic LIS professionals have posted the job advertisements on LIS Link portal to have wider dissemination and publicity. For LIS job advertisements which are posted on LIS Links get more applicants as it has wider access to the LIs professionals and it is updated on regular basis by the Web Site developer.

Therefore, it is suggested that for quick publicity and wider reach to the LIS professionals, the college, university and institutions authorities should also submit the advertisement on-line to the LIS Link for wider dissemination and retrieval.

Table- 5: Source wise Distribution of Number of Posts Advertised (N=267)

\begin{tabular}{|l|l|l|}
\hline $\begin{array}{l}\text { Nature of LIS Job } \\
\text { Advertisements }\end{array}$ & $\begin{array}{l}\text { Number of Posts } \\
\text { Advertised }\end{array}$ & Percentage \\
\hline Permanent Posts & 230 & 83.03 \\
\hline Temporary/Contractual & 47 & 16.97 \\
\hline Total & 277 & 100.00 \\
\hline
\end{tabular}

\subsection{Nature Wise (Permanent/Temporary/ Contractual) Distribution of Job advertisements}

The Table- 6 represents the nature wise (i.e. permanent/temporary) distribution of advertised posts for LIS Professionals. The various advertisements published are either of Permanent nature or of temporary/contractual nature. The Table- 6 reveals that out of a total of 277 no. of posts, 230 nos. of posts $(83.03 \%)$ are of Permanent nature whereas the remaining 47 number $(16.97 \%)$ of posts are of Temporary nature.

Table -6: Nature Wise (Permanent/Temporary) Distribution of LIS Job Advertisements (N=277)

4.6 Level -

\begin{tabular}{|c|c|c|}
\hline Sources of Advertisements & $\begin{array}{c}\text { Number of Posts } \\
\text { Advertised }\end{array}$ & Percentage (\%) \\
\hline Employment News & 139 & 50.18 \\
\hline LIS Link & 102 & 36.82 \\
\hline Employment News + LIS Link & 36 & 13.00 \\
\hline Total & 277 & 100.00 \\
\hline
\end{tabular}

Distribution of Job Advertisements for LIS Posts

Wise

The Table-7 represents the Level wise distribution of no. of posts published in various advertisement media. The advertisements published for various posts are distributed among three different levels, i.e. the Top level, Middle Level and the Bottom level. The various designations like Librarian in different institutions/organisation, Deputy Librarian, Assistant Librarian, and the higher administrative posts are included under Top level. Designations such as PA, SPA, Library Assistant, Information Scientist, etc. are included in the Middle level and the designations such as Library attendant; Library Clerk, etc. are being included under the Bottom Level.

Table -7: Level Wise Distribution Job Advertisements for LIS Posts (N=277)

\begin{tabular}{|l|l|l|}
\hline Levels & No of Posts Advertised & Percentage $(\%)$ \\
\hline Top Level & 122 & 44.04 \\
\hline Middle Level & 82 & 29.60 \\
\hline Bottom Level & 73 & 26.35 \\
\hline TOAL & 277 & 100.00 \\
\hline
\end{tabular}

The survey results as indicated in Table-7 reveals that out of the 277 number of posts, maximum number of advertisements $(122=44.04 \%)$, are advertised for Top level or higher rank posts which is followed by $82(26.35 \%)$ number of posts $\mathrm{x}$ for Middle level or middle rank category whereas $73(26.35 \%)$ number of posts are advertised for Bottom level lower category of posts.

\subsection{Category (Teaching/Non-Teaching) Wise Distribution of No. of Posts}

The Table-. 8 represents the Category wise (Teaching/Non-Teaching) distribution of no. of posts. In the Library \& Information Science profession, there is the availability of both the Teaching/Non-Teaching category of jobs. Thus here the total no. of posts advertised for LIS Professionals are distributed between Teaching/NonTeaching categories. 
Here from the above table it is observed that, out of a total of 277 no. of posts published for LIS professionals, maximum no. of posts $(259=93.5 \%)$ are advertised for non-teaching posts in different organisations whereas only a small no. $(18=6.5 \%)$ of posts are advertised for Teaching positions.

Table - 8: Category (Teaching/Non-Teaching) Wise Distribution of Number of Posts Advertised (N=277)

\begin{tabular}{|l|l|l|}
\hline CATEGORY & NO. OF POSTS & PERCENTAGE (\%) \\
\hline Teaching & 18 & 6.5 \\
\hline Non-Teaching & 259 & 93.5 \\
\hline Total & 277 & 100.00 \\
\hline
\end{tabular}

\subsection{Intake Capacity of LIS Departments for Different Universities and Institutions in India}

Table-9: Intake Capacity of LIS Departments for Different Universities and Institutions in India

\begin{tabular}{|c|c|c|c|c|}
\hline \multirow[t]{2}{*}{ NAME OF THE UNIVERSITY } & \multirow[t]{2}{*}{ STATE } & \multicolumn{3}{|c|}{ INTAKE CAPACITY } \\
\hline & & BLIS & MLIS & $\begin{array}{l}\text { M.Phil. / } \\
\text { Ph.D. }\end{array}$ \\
\hline Aligarh Muslim University & Uttar Pradesh & 60 & 25 & NA \\
\hline Amravati University & Maharashtra & 30 & 20 & NA \\
\hline Assam University, Silchar & Assam & NA & 25 & NA \\
\hline BAM University, Aurangabad & Maharashtra & NA & 22 & 15 \\
\hline $\begin{array}{l}\text { Babasaheb Bhimrao Ambedkar } \\
\text { University, Lucknow }\end{array}$ & Uttar Pradesh & NA & 34 & NA \\
\hline Banaras Hindu University, Varanasi & Uttar Pradesh & NA & 25 & NA \\
\hline $\begin{array}{l}\text { Dr. Bhimrao Ambedkar } \\
\text { University, Agra }\end{array}$ & Uttar Pradesh & 50 & 30 & NA \\
\hline Burdwan University, Bardhaman & West Bengal & 65 & 15 & 10 \\
\hline Calcutta University & West Bengal & 110 & 22 & 15 \\
\hline Delhi University & Delhi & 62 & 46 & NA \\
\hline Dibrugarh University, Dibrugarh & Assam & 24 & 20 & NA \\
\hline Gauhati University, Guwahati & Assam & & 25 & NA \\
\hline Gujarat University, Ahmedabad & Gujrat & 35 & 15 & NA \\
\hline Jadavpur University, Kolkata & West Bengal & 60 & 31 & 10 \\
\hline Jammu University, Jammu & Jammu \& Kashmir & 30 & 15 & NA \\
\hline Kalyani University, Kalyani & West Bengal & 30 & 15 & NA \\
\hline Kurukshetra University, Kurukshetra & Haryana & 40 & 40 & NA \\
\hline Lucknow University, Lucknow & Uttar Pradesh & 20 & 20 & NA \\
\hline $\begin{array}{l}\text { Makhanlal Chaturvedi Rashtriya } \\
\text { Patrakarita Vishwavidyalaya, Bhopal }\end{array}$ & Madhya Pradesh & 20 & 20 & NA \\
\hline Manipur University, Imphal & Manipur & NA & 25 & NA \\
\hline Mizoram University & Mizoram & NA & 15 & 5 \\
\hline North Eastern Hill University, Shillong & Meghalaya & NA & 25 & NA \\
\hline North Bengal University, Siliguri & West Bengal & 56 & 40 & NA \\
\hline North Orissa University, & Orissa & NA & 20 & NA \\
\hline North Maharashtra University, Jalgaon & Maharashtra & NA & 20 & NA \\
\hline NISCAIR , New Delhi & Delhi & NA & 25 & NA \\
\hline Panjab University, Chandigarh & Haryana & NA & 40 & NA \\
\hline $\begin{array}{l}\text { Pt. Ravishankar Shukla University, } \\
\text { Raipur }\end{array}$ & Chhattisgarh & 35 & 20 & 10 \\
\hline Punjabi University, Patiala & Punjab & 28 & 16 & NA \\
\hline Rabindra Bharati University, Kolkata & West Bengal & 40 & 10 & NA \\
\hline RTM Nagpur University & Maharashtra & NA & 80 & 10 \\
\hline Sambalpur University & Orissa & 20 & 5 & NA \\
\hline Shivaji University & Maharashtra & 40 & 15 & NA \\
\hline SMIT Berhampur & Orissa & 48 & 24 & NA \\
\hline SNDT Women's University & Maharashtra & 40 & 12 & NA \\
\hline SRTM University, Nanded & Maharashtra & NA & 20 & NA \\
\hline Tripura University & Tripura & 30 & NA & NA \\
\hline University of Mumbai & Maharashtra & 40 & 20 & NA \\
\hline University of Pune & Maharashtra & NA & 30 & 10 \\
\hline Utkal University & Orissa & NA & 24 & NA \\
\hline Vidyasagar University & West Bengal & 35 & 15 & NA \\
\hline TOTAL & & 1048 & 966 & 85 \\
\hline
\end{tabular}

The Table-9 shows the intake capacity of LIS Departments available for 41Universities of India which reveals that the total intake capacity for BLIS (Bachelor in Library and Information Science) course in different universities is 1048, that for MLIS (master's in Library and Information Science) course is 966, and that for 
M.Phil./Ph.D. course is 85 . Further, the Region wise break up of intake capacity for different courses is shown in the Table -10 .

\subsection{Region Wise break up of Intake Capacity for Different Courses of LIS in India}

Table-10 shows the intake capacity for BLIS, MLIS, and MPhil / Ph.D. students in India. On the basis of available data for Northern India, Western India, Eastern and North Eastern India, the total Intake capacity came to 2099. Region wise analysis shows that out of 2099, Eastern/ North Eastern Region stands on first position with 914 seats $(43.55 \%)$ which is followed by Northern India $(711=33.57 \%)$ and Western India (474 $=22.58 \%$ ).

Table-.10: Region Wise break up of Intake Capacity for Different Courses of LIS in India

\begin{tabular}{|c|c|c|c|c|c|}
\hline \multirow[t]{2}{*}{ REGION } & \multicolumn{3}{|c|}{$\begin{array}{l}\text { INTAKE CAPACITY in University Departments / } \\
\text { Colleges }\end{array}$} & \multirow[t]{2}{*}{ Total } & \multirow[t]{2}{*}{ PERCENTAGE $(\%)$} \\
\hline & BLIS & MLIS & M.Phil./Ph.D. & & \\
\hline Northern India & $\begin{array}{l}345 \\
(16.43 \%)\end{array}$ & $\begin{array}{l}356 \\
(16.96 \%)\end{array}$ & $\begin{array}{l}10 \\
(0.48 \%)\end{array}$ & 711 & 33.87 \\
\hline East/North-East & $518(24.67 \%)$ & 356 & 40 & 914 & 43.55 \\
\hline India & & $(16.96 \%)$ & $(1.90 \%)$ & & \\
\hline Western India & $185(8.81 \%)$ & $254(12.10 \%)$ & $\begin{array}{l}35 \\
(1.67 \%)\end{array}$ & 474 & 22.58 \\
\hline $\begin{array}{ll}\text { Total Intake } \\
\text { Capacity }\end{array}$ & $1048(49.00 \%)$ & $\begin{array}{l}966 \\
(46.02 \%)\end{array}$ & $\begin{array}{l}85 \\
(4.05 \%)\end{array}$ & 2099 & 100.00 \\
\hline $\begin{array}{lr}\text { Expected Pass } \\
\text { Out } \quad \text { (assuming } \\
75 \% \text { ) }\end{array}$ & $786(49.93 \%)$ & $724(45.99 \%)$ & $64(4.06 \%)$ & 1574 & 100.00 \\
\hline
\end{tabular}

Course wise analysis of intake capacity shows that out of 2099, intake capacity for BLIS is 1048 (49.00 $\%$ ) which is followed by MLIS (966=46.02) and M.Phil./Ph.D. ( $84=4.05 \%$ ) which comparatively very low. Further, the above table also represents the data of the intake capacity for different regions to different courses.

The intake capacity for BLIS course is the highest in the East/North East India $(518=24.67 \%)$, which is followed by Northern $(345=16.43 \%)$ and Western $(185=8.81 \%)$ India. The same for the MLIS course is equal for East/North East and Northern India $(356=16.96 \%$, for each). And finally, the intake capacity for M.Phil./Ph.D. candidates is the highest for East/North East India $(40=1.90 \%)$, which is followed by Western $(35=1.67 \%)$ and Northern India $(10=0.48 \%)$.

Since no data is available for the passed out candidates for LIS students of these available Indian universities, however the statistics for the passed out candidates is assumed to be $75 \%$ by the researcher. Thus with this assumption, it is obtained from the above Table-10 that the total no. of passed out candidates out of a total of 2099, is 1574. Due to non -availability of data some universities offering BLIS, MLIS, Ph.D. programme has not been taken into account. In further study, care will be taken to do comprehensive study. It was a small study to know the pattern of intake and out put from the LIS schools.

\subsection{Total Number of Pass Out candidates for LIS courses}

The Table-11 gives a clear picture of the no. of passed out candidates in different courses (assuming $75 \%$ pass out). Out of a total of 1574 , the highest nos. of candidates passed in BLIS $(786=49.93 \%)$, which is followed by MLIS (724=45.99\%), and M.Phil. /Ph.D. (64=4.06\%).

Table - 11: Total No. of Passed Out Candidates for Different Courses $(\mathbf{N}=1574)$

\begin{tabular}{|l|l|}
\hline COURSES & NO. OF PASSED OUT CANDIDATES \\
\hline BLIS & 786 \\
\hline MLIS & 724 \\
\hline M.Phil./Ph.D. & 64 \\
\hline TOTAL & 1574 \\
\hline
\end{tabular}

From the Table-4, it is obtained that the no. of posts advertised for different designations for LIS Professionals is 277 . But as per the available data and assumption by the researcher, the Table -11 reveals that the no. of passed out candidates for different courses in LIS is 1574 whereas 277 (17.60\%) no. of posts have been advertised for employment only, which is very less from the passed out candidates. (Table- 12). 
Status of Job Opportunities and Employment of Library and Information Science Professionals in

\subsection{Status of Number of Passed Out LIS Graduates and Number of Advertised Post}

Table -12: Status of Number of Passed Out LIS Graduates and Number of Advertised Posts

\begin{tabular}{|c|c|c|}
\hline $\begin{array}{c}\text { Number of Passed Out LIS } \\
\text { Graduates }\end{array}$ & $\begin{array}{c}\text { Total Number of Posts for LIS } \\
\text { Jobs Advertised during 2011 }\end{array}$ & Percentage \\
\hline 1574 & 277 & 17.60 \\
\hline
\end{tabular}

5.1 Major findings

\section{Major findings, Suggestions and Recommendations}

Based on the analysis and interpretation of data following findings are drawn from the study:

\subsection{Media / Sources where Advertisements Published}

$>$ The entire study is conducted using the two sources, i.e. the Employment News and LIS Link, an LIS Job Portal. From the content analysis of the two sources, during the periods from January $1^{\text {st }}$ to December $31^{\text {st }}$ for the year 2011, it is found that out of a total of 277 number of posts advertised in the two mentioned sources, 139 (50.18\%) number of posts is advertised in the Employment News, 102 (36.82\%) number of posts is advertised in the LIS Link whereas. 36 (13\%) number of posts advertised is found in both the two sources.

\subsection{Month Wise Distribution of Posts}

$>$ While consulting the two sources, it is found that the frequency of distribution of number of posts advertised in different months is different. It is found from the study that that maximum no. of posts is advertised in the month of February, January and March respectively. Out of a total of 277 posts advertised , maximum ( $56 .=20.21 \%$ ) number of posts are advertised in the month of February, which is the highest in the year 2011 which is followed by January $(52=18.77 \%)$ and March $(47=16.97 \%)$. Whereas very less number of posts is advertised in the month of April, August and October $(9=$ $3.24 \%$ ) posts are advertised in each of these months.

\subsection{State Wise Distribution of Posts}

$>$ Moreover the study also reveals that the frequency of distribution of the published advertisements also varies State wise. It is found that out of a total of 28 states in India, the advertisements for the LIS professionals are published from 24 States. The highest no. of post for the LIS professionals is advertised for Delhi. Out of a total of 277 no. of posts, 96 no.(34.65\%) of posts are advertised for the libraries and other govt. and non govt. institutions located in Delhi which is followed by Uttar Pradesh $(38=13.71 \%)$, Madhya Pradesh $(22=7.94 \%)$ and West Bengal $(21=7.58 \%)$.Few no. of posts is advertised for Arunachal Pradesh, Assam Goa, Jharkhand, and Karnataka. Very few no (1 or 2) no. of posts is advertised for these states, the percentage for which being the $0.36 \% \& 0.72 \%$.

\subsection{Category Wise Distribution of Advertisements}

$>$ The study also reveals the Category (Reserved/Unreserved) wise distribution of frequency of no. of posts. A good no. of posts advertised is reserved for different categories such as OBC, SC, ST, and for PH candidates. Out of a total of 277 no. of posts, 73 no. (26.36\%) of posts is reserved for these different categories. And the rests i.e. 204 nos. (73.64\%) of posts is unreserved. Out of the total reserved posts, the highest nos. $(33=11.91 \%)$ is reserved for OBC candidates and the least nos. $(5=1.8 \%)$ is reserved for Physically Handicap candidates.

\subsection{Designation and Level Wise Distribution of Advertisements}

$>$ The study also shows the Designation wise frequency of distribution of no. of posts. Here the various posts published under different designations are included under 19 different designations. It is obtained from the analysis part that under variety of designations, the highest no. of posts is advertised for the designation, 'Library Assistant/Cataloguer'. A total of 40 (14.44\%) no. of posts out of 277, is advertised under this designation which is followed by 'Library and Information Assistant' with 39 (14.07\%) and 'Library Attendant' with 33 (11.91\%) no. of posts. It can also be seen from the above table that only $2(0.722 \%)$ posts are advertised for 'School Librarian' which is the least no. of post advertised under any designation.

$>$ From the study it is found that, the various posts advertised under different designations are of two natures; either of Permanent or of Temporary/contractual nature. The frequency of total no. of posts is distributed between these two types of nature. It is observed that out of a total of 277 no. of posts, 230 
nos. $(83.03 \%)$ are of Permanent nature and the remaining 47 no. (16.97\%) of posts are of Temporary nature.

\subsection{Level / Ranks / Hierarchy Wise Distribution of Advertisements}

$>$ The job advertisements published are for different levels of LIS Profession. The advertisements published for various posts are distributed among three different levels, i.e. the Top level, Middle Level and the Bottom level. The various designations like Librarian in different institutions/organisation, Deputy Librarian, Assistant Librarian, and the higher administrative posts are included under Top level. Designations such as PA, SPA, Library Assistant, Information Scientist, etc. are included in the Middle level and the designations such as Library attendant; Library Clerk, etc. are being included under the Bottom Level.

$>$ It is found through the study that out of the total no. (277) of posts, 122 nos. (44.04\%), are advertised for Top level; 82 nos. (29.60\%) for Middle level and 73 nos. (26.35\%) of posts are advertised for Bottom level.

\subsection{Category Wise / Type of Job Wise Distribution of Advertisements}

$>$ In the Library \& Information Science profession, there is the availability of both the Teaching/NonTeaching type of jobs. Thus here, the total no. of posts advertised for LIS Professionals are distributed between Teaching/Non-Teaching categories. The study reveals that out of a total of 277 no. of posts, maximum no. of posts $(259=93.5 \%)$ is advertised for non-teaching profession and few nos. (18 $=6.5 \%)$ of posts are advertised for Teaching profession.

$>$ On the basis of available data, every year in India, 2099 nos. of students get admitted in various courses like BLIS, MLIS, M.Phil./ Ph.D.

$>$ Assuming 75\% success rate, 1574 students pass out every year from various universities in India. But the no. of post advertised is only 277 , which is only $17.60 \%$ of the total pass out students. This indicates that there is a huge gap between the Library Science graduates produced and their employability.

\subsection{Suggestions and Recommendations}

Based on the entire studies and analysis with the available data, the following suggestions can be made so that more and more jobs can be tapped by the LIS Professionals:

$>$ There should be any mechanism which must be developed so as to track all the advertisements published for various institutions to different localities and also it must be maintained regularly.

$>$ It is observed that the ratio of candidates acquiring LIS degree and their employability is 5:1 (approx.). Thus the ratio indicates a huge gap between the entities. On the basis of this, the following points can be recommended:

- The government should take initiative to create and recruit vacant positions for different institutions/organisation as and when necessary. The government should also pay attention to fill the different vacant posts in various institutions.

- The government, particularly the State governments should pay their attention to Public Libraries. State governments should implement Library Legislation so that as much posts can be created for public libraries.

- No further new Department for Library Science should be opened. There should be a regulatory body to monitor the syllabus, intake capacity, infrastructure for existing and emerging institutions offering Library and Information Science courses.

- There should be a Professional Body to look up the matters such as the advertisements published annually for Library Science Professionals, emerging human resources and the requirements.

- The Professional Library Associations like ILA, IASLIC, etc. should also collect and maintain records from different institutions and organisations about their library positions, their requirements, etc. and they should work for the well-being of Library Profession.

To meet the current challenges in view of implementation of ICT in Libraries, the Library Science Schools in India should constantly upgrade their curriculum and train their students in such a way so that they can cope up with the emerging trends and can compete and sustain in this new environment. 
$>$ Moreover, the Library Professionals should see new avenues and new job areas such as in corporate sectors for their survival as IT Professionals are coming in our way to grab our job, if LIS Professionals do not make themselves fit in the new changing environment.

\subsection{Scope for further Research}

Due to the limitation of time, the researcher is unable to scan the newspapers published from different regions and localities. The work is carried out by consulting The Employment News mainly and partially the LIS Link. Thus the work is done on a small scale and a rough idea is produced. However, the work can be done on a large scale by scanning various sources of advertisements published from different regions and localities and also consulting different available LIS Job Portals, a relevant and a clear picture of the work can be arrived at. Moreover the work is done for the previous year (2011) only, which may be taken as a Pilot study for the further and preceding years. The same study can be done on last 5 years or 10 years to come on the concrete results/findings.

\section{Conclusion}

This is a preliminary study taking with consideration of advertisements published during the year 2011. This may be carried out over the period of 5 years or more to get a reliable picture for intake capacity of students and how many students are getting jobs may be analysed and discussed in details. It is very interesting finding that many universities have been offering LIS education at different levels (BLIS, MLIS, and M.Phil. /Ph.D. levels) but number of post for teaching positions are comparatively published in very less numbers which shows that teaching posts are perhaps not created in sufficiently or posts are perhaps kept lying vacant on account of various reasons, which needs a further investigation.

It is further suggested that more numbers of posts for teaching positions should also be created so that fresh NET and Ph.D. degree holders may get job for teaching or research. It has also been observed from the present study that number of vacancies for JRF/SRF have not been published during the year 2011, which needs serious attention from the university departments to bring more number of projects to engage fresh JRF/ SRF /RA for research in the area of Library and Information Science. The universities have been taking steps for opening NET Coaching centres for the students who want to appear at the Net examinations. The fresh LIS students pursuing MLIS course should be courage to attend the Net coaching centre and try to qualify NET/JRF exams conducted by UGC or SLET conducted by different state governments which will give an opportunity to serious MLIS passed out and Net qualified students to pursue research programme in universities.

From the data available for intake capacity for BLIS, MLIS, and Research Programme and number of fresh graduates who are passed out, it was found that the number of posts advertised for LIS jobs are very less when we compare it with the availability of job avenues / opportunities in LIS profession. Form the above findings it is evident that production of fresh graduates are more in comparison to the number of jobs available in the LIS job market which creates a serious problems for the LIS Professionals to in searching suitable jobs for themselves. There is a great competition amongst the LIS professionals to get job which needs attention of the State as well as Central Governments to create more job avenues for the LIS professionals in schools, colleges, universities, institutions Therefore the Government of India and the respective State Governments should also create/ sanction requisite number of posts in different Schools, Colleges, Universities, Institutions, Rural and Public libraries, Corporate sectors etc so that more and more fresh graduates may be appointed in the state and central governments educational institutions and public/ rural libraries and other government departments and ministries and special libraries. It is hoped that during XII plan, more and more posts will be sanctioned in the educational institutions while implementing the recommendations of the National Knowledge Commission. The future of LIS professionals is bright and library profession sector would give more job avenues to the fresh library science graduates, post-graduates, and certificate, diploma degree holders in the coming years to come. There would be also more job avenues in the higher educational institutions like colleges , technical institutions, colleges and universities for higher as well as lower level posts.

\section{Acknowledgements}

The authors are thankful to Prof. Somnath Dasgupta , Hon'ble Vice-Chancellor, Assam University, Silchar for his encouragement and support. Thanks are also due to Prof. Sumanash Dutta, Dean, Swami Vivekananda School of Library Sciences, Assam University, Silchar for his valuable and critical suggestions.

\section{References}

[1] Editorial. (2007). Library and Information Science Education in Uttar Pradesh. DESIDOC Bulletin of Information Technology, 27(5), 41-47.

[2] Editor, (2007). Trends, challenges and future of library and information science education in India. DESIDOC Bulletin of Information Technology, 27(5), 17-26.

[3] Alimohammadi, D., Jamali, H. R. (2011). Common problems of library and information science education in Asian developing countries: A review article. International Journal of Information Science and Management, 1(2), 80-92. 
[4] Bharat Kumar (2010). Library and information science education in South India: Perspectives and challenges. DESIDOC Journal of Library and Information Technology, 30(5), 74-82.

[5] Dasgupta, Arjun (2009). Preparing future librarians in India: A vision for LIS schools of Indian Universities in the 21st century. Presented at the World Library and Information Congress: 75th IFLA General Conference and Council, Milan, 23-27 August 2009.

[6] Du, Y., Stein, B., \& Martin, R. S. (2007). Content analysis of an LIS job database: A regional prototype for a collaborative model. Libri, 57, 17-26.

[7] Halder, Sambhu Nath (2009). Multimodal roles of library and information science professionals in present era. International Journal of Library and Information Science, 1(6), 092-099.

[8] Jeevan, V. K. J. (2003). Job prospects in library \& information science: A study of vacancies notified in the employment news from 1998 to 2001. Annals of Library and Information Studies, 50 (2), 62-84.

[9] Joshi, M. K. (2010). Library and information science education in India: Some government initiatives. DESIDOC Journal of Library \& Information Technology, 30 (5), 67-73.

[10] Karisiddappa, C. R. (2004). LIS curriculum from the developing countries. World Library and Information Congress: 70th IFLA General Conference and Council.

[11] Krishan Kumar., and Sharma, J. (2010). Library and information science education in india: A historical perspective. DESIDOC Journal of Library \& Information Technology, 30 (5), 3-8.

[12] Kurup, M. R. (2006). Curriculum design: A reality check in affiliating universities. University News, 44(50), 1-5.

[13] Mahapatra, G. (2006). LIS Education in India: Emerging paradigms, challenges and propositions in the digital era. In Asia-Pacific Conference on Library \& Information Education \& Practice 2006 (A-LIEP 2006), Singapore, 3-6 April 2006.

[14] Singh, S. (2000). Library and Information Science Education India: Growth and trends. University News, 38 (6), 54-48.

[15] Singh, S.P. (2003). Library and Information Science Education in India: Issues and trends. Malaysian Journal of Library \& Information Science, 8 (2), 1-17.

[16] Sinha, Manoj Kumar. 2011. Scenario of Library and Information Science Education and Research in North Eastern Region of India: An Overview. In: LIS Education, Research and Training : Vision 2020 (100 Years of LIS Education in India ) IATLIS 2011 : Papers of the XXVIII National Conference on LIS Education in India organised by AITLIS, and DLIS, Gujarat University, Ahmedabad during November 26-28, 2011, (Eds: Jagtar Singh and Trishanjit Kaur ), AITLIS, Patiala, Pp.510-530. (ISBN: 978-81920456-1-0) (Paperback).

[17] Tripathi, Tridib (2011). Need of quality assurance and accreditation of library and information science in India. . In: LIS Education , Research and Training : Vision 2020 (100 Years of LIS Education in India ) IATLIS 2011 : Papers of the XXVIII National Conference on LIS Education in India organised by AITLIS, and DLIS, Gujarat University, Ahmedabad during November 26-28, 2011, (Eds: Jagtar Singh and Trishanjit Kaur ), AITLIS, Patiala, Pp.418-425. (ISBN: 978-81-920456-1-0) (Paperback).

[18] Varalakshmi, R. S. (2007). Need for national consensus on library and information science education in India. DESIDOC Bulleting of Information Technology, 27 (2), 13-20.

[19] Varalakshmi, R. S. R. (2010). Library and information science education in South India: Perspectives and challenges. DESIDOC Journal of Library and Information Technology, 30 (5), 19-31.

[20] Yagnik, Shailesh R. (2011). Job market for LIS professionals in India. In: LIS Education, Research and Training : Vision 2020 (100 Years of LIS Education in India ) IATLIS 2011 : Papers of the XXVIII National Conference on LIS Education in India organised by AITLIS, and DLIS, Gujarat University, Ahmedabad during November 26-28, 2011, (Eds: Jagtar Singh and Trishanjit Kaur ), AITLIS, Patiala, Pp.362-372. (ISBN: 978-81-920456-1-0) (Paper Back).

[21] XXVIII IATLIS National Conference, 2011. LIS Education, Research and Training : Vision 2020 (100 Years of LIS Education in India ) IATLIS 2011 : Papers of the XXVIII National Conference on LIS Education in India organised by AITLIS, and DLIS, Gujarat University, Ahmedabad during November 26-28, 2011, (Eds: Jagtar Singh and Trishanjit Kaur ), AITLIS, Patiala, 559p. (ISBN: 978-81-920456-1-0) (Paperback).

\section{Web Sites Visited:}

http://myjurnal.um.edu.my/filebank/published article/1932/262.pdf (visited on 10-04-12).

http://www.news24online.com/Library-and-Information-Science-Education-in-India--ptions,-pportunities-andPlaces_career24_23.aspx (visited on 10-04-12).

http://www.ifla.org/files/hq/pa pers/ifla75/126-dasgupta-en.pdf (visited on 10-04- 12).

http://publications.drdo.gov.in/gsdl/collect/dbit/index/assoc/HASHd651.dir/dbit3005003.pdf (visited on 16-04-2012)

http://www.bibliotheksportal.de/fileadmin/user_upload/content/bibliotheken/international/dateien/_ind4_indien_1.pdf

(visited on 18-04-2012)

http://shodhganga.inflibnet.ac.in/bitstream/10603/1205/9/09 chapter\%201.pdf (visited on 18-04-2012).

http://eprints.rclis.org/bitstream/10760/10175/1/D7505896.pdf (visited on 02-05- 2012).

http://publications.drdo.gov.in/gsdl/collect/dbit/index/assoc/HASH0f6a.dir/dbit3005067.pdf

(visited on 02-05-2012).

http://publications.drdo.gov.in/gsdl/collect/dbit/index/assoc/HASHe50e.dir/dbit2705017.pdf (visited on 06-05-2012)

http://www.webpages.uidaho.edu/ mbolin/jogindersingh-shahid.htm (visited on 06-05-2012)

http://www.librijournal.org/pdf/1999-4pp236-242.pdf (visited on 06-05-2012) 